
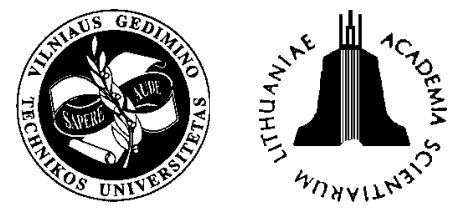

ISSN 1648-4142 TRANSPORT

http:/www.vtu.lt/english/editions

TRANSPORT - 2004, Vol XIX, No 5, 219-223

\title{
APPLICATION OF FUEL CELLS IN TRANSPORTATION
}

\author{
Antanas Žiliukas \\ Dept of Aviation Mechanics, Vilnius Gediminas Technical University, \\ Rodūnès kelias 30,LT-02187 Vilnius, Lithuania.E-mail: antanas.ziliukas@ktu.lt
}

Received 2004-06-30; accepted 2004-06-30

\begin{abstract}
The development of fuel sort of vehicles assumes a wide spectrum of application in America and Europe. Safety assessment is needed for car exploitation using hydrogen fuel. Therefore this article covers the control methodology of defects adapting the science advancement for hydrogen fuel operation. To achieve this aim the damage prevention methodology of mechanic phenomena and damage modeling for hydrogen fuel cells is suggested. In the presented methodology the methods and steps of safety assessment are discussed.
\end{abstract}

Keywords: fuel cells, hydrogen, safety, damage.

\section{Introduction}

In principle, a fuel cell operates like a battery. Unlike a battery, a fuel cell does not run down or require recharging. It will produce energy in the form of electricity and heat as long as fuel is supplied.

A fuel cell consists of two electrodes sandwiched around an electrolyte. Oxygen passes over one electrode and hydrogen over the other, generating electricity, water and heat.

Hydrogen fuel is fed into the "anode" of the fuel cell. Oxygen (or air) enters the fuel cell through the cathode. Encouraged by a catalyst, the hydrogen atom splits into a proton and an electron, which take the different paths to the cathode. The proton passes through the electrolyte. The electrons create a separate current that can be utilized before they return to the cathode, to be reunited with the hydrogen and oxygen in a molecule of water.

A fuel cell system which includes a "fuel reformer" can utilize the hydrogen from any hydrocarbon fuel - from natural gas to methanol, and even gasoline. Since the fuel cell relies on chemistry and not on combustion, the emissions from this type of a system would still be much smaller than the emissions from the cleanest fuel combustion processes [1].

Proton Exchange Membrane (PEM). These cells operate at relatively low temperatures (about 175 degrees $\mathrm{F}$ or 80 degrees $\mathrm{C}$ ), have high power density, can vary their output quickly to meet shifts in power demand and are suited for application - such as in automobiles - where quick start is required. The proton exchange membrane is a thin plastic sheet that allows hydrogen ions to pass through it. The membrane is coated on both sides with highly dispersed metal alloy particles (mostly platinum) that are active catalysts. The electrolyte used is a solid organic polymer poly-perflourosulfonic acid. The solid electrolyte is an advantage because it reduces corrosion and management problems. Hydrogen is fed to the anode side of the fuel cell where the catalyst encourages the hydrogen atoms to release electrons and become hydrogen ions (protons). The electrons travel in the form of an electric current that can be utilized before it returns to the cathode side of the fuel cell where oxygen has been fed. At the same time the protons diffuse through the membrane (electrolyte) to the cathode where the hydrogen atom is recombined and reacted with oxygen to produce water, thus completing the overall process. This type of fuel cell is, however, sensitive to fuel impurities. Cell outputs generally range from 50 to $250 \mathrm{~kW}$.

Direct Methanol Fuel Cells (DMFC). These cells are similar to PEM cells as they both use a polymer membrane as the electrolyte. However, in DMFC the anode catalyst itself draws the hydrogen from the liquid methanol, eliminating the need for a fuel reformer. Efficiencies of about $40 \%$ are expected with this type of fuel cell, which would typically operate at a temperature between $120-190$ degrees $\mathrm{F}$ or $50-100$ degrees $\mathrm{C}$. This is a relatively low range, making this fuel cell attractive for tiny to mid-sized applications to power cellular phones and laptops. Higher efficiencies are achieved at higher temperatures. A major problem, however, is fuel crossing from the anode to the cathode without producing electricity. Many com- 
panies said they solved this problem, however.

A protonic ceramic fuel cell (PCFC), a new type of fuel cell is based on ceramic electrolyte material that exhibits high protonic conductivity at elevated temperatures. PCFCs share the thermal and kinetic advantages of high temperature operation at $700 \mathrm{de}-$ grees Celsius with molten carbonate and solid oxide fuel cells, while exhibiting all of the intrinsic benefits of proton conduction in polymer electrolyte and phosphoric acid fuel cells (PAFCs). The high operating temperature is necessary to achieve very high electrical fuel efficiency with hydrocarbon fuels. PCFCs can operate at high temperatures and electrochemically oxidize fossil fuels directly to the anode. This eliminates the intermediate step of producing hydrogen by a costly reforming process. Gaseous molecules of the hydrocarbon fuel are absorbed on the surface of the anode in the presence of water vapor and hydrogen atoms are efficiently stripped off to be absorbed into the electrolyte, with carbon dioxide as the primary reaction product. Additionally, PCFCs have a solid electrolyte so the membrane cannot dry out as with PEM fuel cells, or liquid can't leak out as with PAFCs.

\section{Fuel Cells in transportation}

All major automotive manufacturers have a fuel cell vehicle either in development or in testing right now, and Honda and Toyota have already begun leasing vehicles in California and Japan. Automakers and experts speculate that the fuel cell vehicle will not be commercialized until at least 2010. Fuel cells are also being incorporated into buses, locomotives, airplanes, scooters and golf carts.

Fuel cell automobiles are an attractive advance from battery-powered cars. They offer the advantages of battery-powered vehicles, but can also be refueled quickly and could go longer between refueling.

Fuel cells utilizing hydrogen as a fuel would be zero emission vehicles and those using other fuels would produce near-zero emissions. They are also more efficient than "grid"-powered battery vehicles. In addition, fuel cell cars could produce fewer "system-wide" releases of greenhouse gases - taking into account all emissions associated with resource recovery, fuel processing and use.

BMW announced plans to unveil a hydrogenpowered Mini Cooper, featuring an internal combustion engine (ICE) similar to its Clean Energy cars. The Mini Cooper features an advanced hydrogen fuel storage tank that utilizes the same space as a conventional fuel storage tank.

BMW and Delphi Automotive unveiled their first development vehicle featuring a solid oxide fuel cell auxiliary power unit (APU). APU provides sufficient energy for existing mechanically-driven sub-systems, such as the air conditioning and water pumps. APU could also be used to run devices while the vehicle is idle.

BMW AG plans to fit an unspecified number of 7 Series sedans with fuel cells from UTC Fuel Cells. The vehicle will run on a hydrogen combustion engine; the fuel cell will power the car on-board electrical system.

BMW will develop hydrogen fuelled FC forklift trucks, deploying about 2,000 in the company's own facilities prior to marketing them to other users.

DaimlerChrysler plans to field-test eight hydrogen-powered fuel cell vehicles (FCVs) on public roads in Japan next year. F-Cell prototype FCVs to be tested are based on its Mercedes-Benz A-class subcompact car and have a top speed of approximately 140 kilometers per hour (about 87 miles per hour). FCV is able to travel 150 kilometers (about 93 miles) without needing to refill its 1,8-kilogram compressed hydrogen fuel storage tank.

Daimler-Benz began road testing a fuel cell van, NECAR (New Electric Car), in 1993. Daimler has developed and operated four generations of fuel cell passenger vehicles, utilizing a variety of fuels. In November of 2000, DaimlerChrysler presented NECAR 5 , the latest version, in Berlin. NECAR 5 runs on methanol, unlike its predecessor, NECAR 4, which ran on hydrogen.

Daimler is a part owner of Ballard and partners with Ford in several ventures related to the development and sale of fuel cell vehicles. Daimler has committed \$725 million into its partnership with Ballard and Ford.

Daimler presented a fuel cell as a compact auxiliary power unit (APU) in an internal combustion Mercedes-Benz S class model (2/00).

Italy's De Nora S.p.A works with PEM fuel cells for buses and marine applications. The company spun off its fuel cell R \& D unit to form De Nora Fuel Cells.

The company is cooperating with Renault and Peugot/Citroen on fuel cell car projects. De Nora supplied the fuel cell engine demonstrated in the Coval truck.

Fiat presented the prototype of its first fuel cell car, Seicento Elettra H2 Fuel Cell. The two-seater car was developed with the support of the Italian Ministry of the Environment and runs on hydrogen (6/01).

PSA Citroen is working with Renault to speed the development of a commercially viable fuel cell car by 2010. PSA Peugeot/Citroen is leading the HYDRO-GEN project, building a second generation PEMFC car powered by a De Nora stack and compressed hydrogen. 
Renault SA of France and Nissan Motor Co. have decided to develop cars with a fuel cell that runs on gasoline. The companies will spend $\$ 714$ million on the project and will market the fuel cell vehicles as early as 2005. Renault is also working with PSA Citroen to speed the development of a commercially viable fuel cell car by 2010 .

Renault has designed, built and tested a fuel cell powered Laguna Estate. Renault built its own fuel cell for the car (1/99).

FEVER ("Fuel cell Electric Vehicle for Efficiency and Range") is a Renault station wagon powered by PEM fuel cell engine fueled by stored liquid hydrogen.

Volkswagen introduced its first fuel cell-powered car at the California Fuel Cell Partnership headquarters' opening. The zero emission vehicle (ZEV) is called Bora HyMotion, based on Jetta. The HyMotion fuel cell engine runs on hydrogen and has power output of $75 \mathrm{~kW}$. (11/00).

Volkswagen is involved with CAPRI, a project that will deliver a prototype methanol FCV. Ballard will supply the fuel cell and Johnson Matthey a "Hot Spot" reformer.

In a joint project, Volvo and Volkswagen have announced plans for a methanol-fueled PEM fuel cell hybrid "Golf" type car.

\section{Hydrogen safety}

Many questions have been raised regarding hydrogen safety as an energy carrier. Hydrogen is highly flammable and requires low hydrogen to air concentration for combustion. However, if handled properly, hydrogen is as safe or safer than most fuels, and hydrogen producers and users have generated an impeccable safety record over the last half-century.

Comprehensive studies have shown that hydrogen presents less of a safety hazard than other fuels including gasoline, propane, and natural gas. In 1997, Ford Motor Company in conjunction with the Department of Energy published a "Hydrogen Vehicle Safety Report" in which it concluded, "the safety of a hydrogen [Fuel Cell Vehicle] system to be potentially better than the demonstrated safety record of gasoline or propane, and equal to or better than that of natural gas." The study cited hydrogen higher buoyancy, higher lower flammability limit, and much higher lower detonation limit as major contributors to hydrogen greater safety potential.

Specifically, the study compared the safety of the various fuel systems during collisions in open spaces, collisions in tunnels, and over the fuels entire lifecycle. The studies found that in an open space collision, hydrogen powered fuel cell vehicles were safer than gasoline, propane, or natural gas powered internal combustion engine (ICE) vehicles because of four factors.

Hydrogen carbon fiber composite tanks are very resilient to rupture even upon high impact. In general, hydrogen tanks and operating systems are designed to withstand without rupture or puncture pressures 2,25 to 3,5 times their operating pressure, highspeed collisions, and direct shots from high-powered rifles and handguns.

Hydrogen possesses density only $7 \%$ that of air, and has a high buoyancy so that it will rise and dissipate without wind or ventilation. Natural gas density is $55 \%$ that of air while both gasoline (3,4 to 4 times heavier) and propane (1,52 times heavier) vapors are heavier than air. Hydrogen also has a diffusion coefficient 3,8 times greater than natural gas, 6,1 times greater than propane vapor, and 12 times greater than gasoline vapor. Consequently, hydrogen gas rises and diffuses laterally much faster than natural gas, propane, or gasoline. In open spaces, hydrogen greater dispersion rate should translate into fewer fires. Also, for hydrogen to burn downward, i.e. when the point of ignition is above the gas, the hydrogen/air mixture must be at least $9 \%$ hydrogen or higher ("if the ignition source is above $10 \%$ or less flammable mixture of hydrogen, then the hydrogen below the source will not be ignited"). In comparison, methane has a downward propagating lower flammability limit of $5,6 \%$ making methane more likely than hydrogen to be ignited by a source point located above the gas/air mixture.

A fuel cell vehicle could carry approximately $60 \%$ less energy than an internal combustion vehicle because a fuel cell vehicle is more efficient. If combusted, a fuel cell vehicle hydrogen would generate less thermal energy than the comparable amount of natural gas, propane, or gasoline for an internal combustion engine vehicle. The hydrogen gas would also burn quicker in the event of a fire because it has a burning velocity 7 times greater than natural gas or gasoline. The result could be a quick plume of fire that does not cause as much damage as a gasoline fire.

A hydrogen powered fuel cell vehicle will possess many safety sensors and devices that will stop the flow of hydrogen through the system if a leak is detected or in the event of an impact. By sealing the tank, the safety measures will decrease the chance that a rupture in a line will cause a continuous leak that would lead to hydrogen concentration sufficient for ignition. The vehicle design will also cut electrical power from the battery eliminating an ignition source.

In a tunnel collision, the same properties that 
made hydrogen safer for open-air collisions should also make hydrogen safer. Hydrogen gas will disperse quicker than other fuels, although it could create a larger initial plume of gas potentially coming into contact with more ignition sources than a natural gas plume.

If handled properly, the entire lifecycle of the hydrogen should prove to be safer than those of natural gas, propane, and gasoline. The production and transportation of hydrogen would pose fewer direct public hazards because hydrogen gas pipelines or hydrogen tanker trucks present less of a public risk than oil tank trucks (see above). Moreover, hydrogen is not toxic and will not contaminate the environment like propane, gasoline, or even a natural gas spill could.

Hydrogen safety record provides no evidence of an unusual safety risk. Liquid hydrogen trucks have carried on the nation's roadways an average 70 million gallons of liquid hydrogen per year without major incident. A high hydrogen gas mixture called "town gas" used to light streetlights and houses has been determined to have equal safety rating as similarly used natural gas. Hydrogen has been handled and sent through hundreds of miles of pipelines with relative safety for the oil, chemical, and iron industries. Moreover, NASA has used liquid hydrogen as its major fuel source for the last half-century without major incident.

As practice shows steels used for the pressure vessels for petrochemical applications may be submitted to high pressures at temperature [2]. The hydrogen environment may produce a phenomenon, named hot hydrogen attack, which results from a reaction between hot hydrogen and the carbides of the steel which may be destabilized. Newly developed steel grades (vanadium modified versions of CrMo steels with $2 \frac{1}{4} \mathrm{Cr}, 3 \mathrm{Cr}$ and $9 \mathrm{Cr}$ ) offer a combination of improved creep and hydrogen attack resistances [3-5]. The development and adjustment of a mechanic suitable computer model must predict the behavior of materials. As a first step the damage model could be developed in the widely range of temperature and resistance to the material embrittlement due the temperature.

As illustrated in Fig 1, some of the components of fuel cells important to safety may be recommended from the safety perspective.

The selection of components is the first step of the three step general approach to the safety of fuel cells. This approach is illustrated in Fig 2. The second step involves performing the damage studies for the selected components and the third step is the application of the results of these studies in appropriate damage actions.

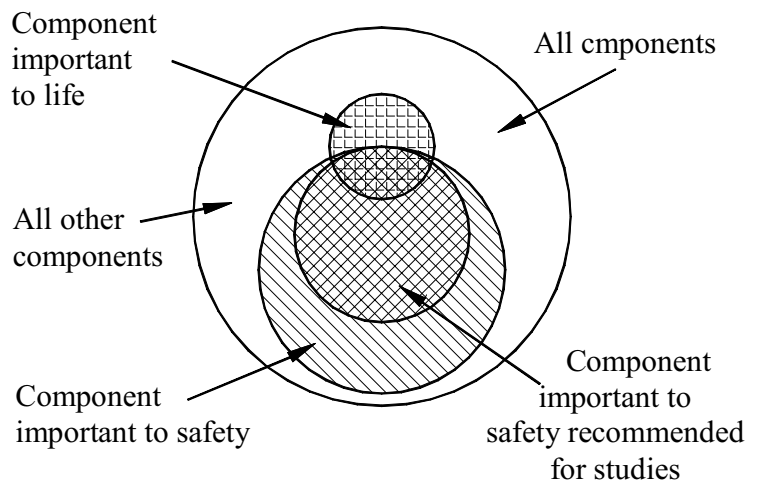

Fig 1. Grouping components of fuel cells for safety

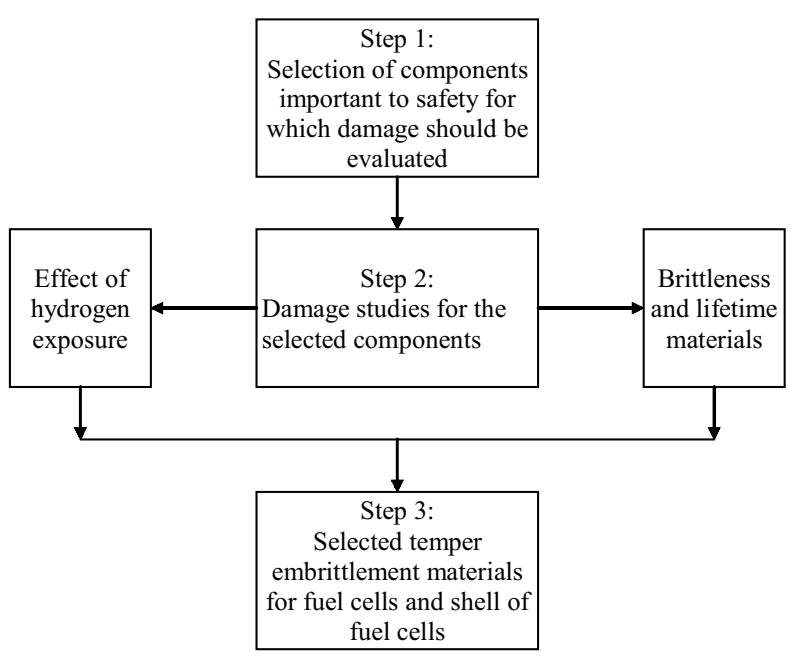

Fig 2. The selection methodology of material for fuel cell/ shell manufacturing

According to the exposure riskiness of hydrogen the fuel cells and vessels must be covered or have large strength in the case of dynamic loading. Therefore it is important to place the fuel cells in a special shell to have the safe structure according to the dynamic influence or impact. Consequently, a strong and light, damageproof material is needed. If the fuel cells need a heatproof material then the heat impact to the shell is less important.

\section{Conclusions}

1. The review of fuel cells used in the transport of Europe is given.

2. The analysis of fuel cells shows that the exposure properties of hydrogen make an influence on its adaptability.

3. The mechanical models are needed for behavior evaluation of cell material using the hydrogen fuel and its equipment safely. 
4. Firstly, for the mechanical model creation because of fracture and catastrophe prevention the control methodology of damages according to the wide-ranging temperature is needed.

5. The control methodology of damages is important for safety guaranty. It is shown in Fig 1.

6. For fuel cell protection in the case of accident the fractureproof cells and shells of fuel are used. The material selection methodology for fuel cell/shell manufacturing is presented in Fig 2.

\section{References}

1. http:/www.fuelcells.org. The Online Fuel cell Information Center.

2. Baylac, G.; Bocquet, P.; Hukelmann, F.; Lejuste, P. New Advanced Steels for Economic and Safe use in the Pressure Equipment Industry. EPRC Bulletin, N 5. European Communities, 2001, p. 23-47.

3. Schlögl, S. M.; Van Der Giesen, E.; Van Leeuwen, Y. On Methane Generation and Decarburization in LowAlloy Cr-Mo Steels During Hydrogen Attack, Metal. Mater. Trans. A, Vol 31, 1998, p. 215-137.

4. Van Der Burg, M. W. D.; Van Der Griessen, E.; Tvergaard, V. A. Continuum damage analysis of hydrogen attack in a $2.25 \mathrm{Cr}-1 \mathrm{Mo}$ Vessel. Mat. Sci. and END. A, Vol 241, 1998, p. 1-13.

5. Cheviet, A.; Bocquet, P.; Coudert, E. Elements de Choix des Aciers Cr Mo (V) Evoluties pour Appareils a Pression Utilises an Petrochimie, IAFIAP, Paris, 1998. 